Supporting Information

for

\title{
Selective Detection of Dengue Virus Serotypes Using Tandem Toehold-mediated Displacement Reactions
}

Mingxuan Gao, Jesse J. Waggoner, Sidney M. Hecht and Shengxi Chen

Including:

Nine pages

Two tables

Six figures 
Table S1. Sequences of the DNAs used in this study. The toeholds are shown in italics. Recognition regions are shown in boldface. Amplification regions are underlined.

\begin{tabular}{|c|c|c|c|c|}
\hline Name & $\begin{array}{l}\text { Nucleic Acid } \\
\text { Type }\end{array}$ & Sequence $\left(5^{\prime}\right.$ to $\left.3^{\prime}\right)$ & Modification & Bases \\
\hline $\begin{array}{l}\text { Type1 - } \\
\text { DNA } 1\end{array}$ & DNA & $\begin{array}{l}\text { TGC TCT TCC CGA } \underline{\boldsymbol{A} \boldsymbol{A} \boldsymbol{A}} \\
\underline{\boldsymbol{C A G} \text { CAT ATT GAC GCT }} \\
\underline{\text { GGC AAC TCC CAC TCA }} \\
\text { ACT GCC TGG TGA TAC } \\
\text { GAG GAT GGG CA }\end{array}$ & $\mathrm{N} / \mathrm{A}$ & 71 \\
\hline $\begin{array}{l}\text { Type2 - } \\
\text { DNA } 1\end{array}$ & DNA & $\begin{array}{l}\text { TGC TCT TCC CGA } \underline{\boldsymbol{A} \boldsymbol{A} \boldsymbol{A}} \\
\underline{\boldsymbol{C A T} \text { TTC ATG TTA GTT }} \\
\underline{\text { TTG CCT TCT CAC TCA }} \\
\text { ACT GCC TGG TGA TAC } \\
\text { GAG GAT GGG CA }\end{array}$ & $\mathrm{N} / \mathrm{A}$ & 71 \\
\hline $\begin{array}{l}\text { Type3 } \\
\text { DNA } 1\end{array}$ & DNA & 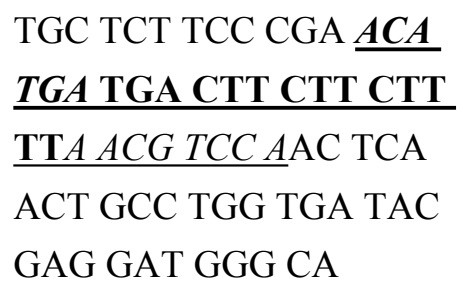 & N/A & 71 \\
\hline $\begin{array}{l}\text { Type4 - } \\
\text { DNA } 1\end{array}$ & DNA & $\begin{array}{l}\text { TGC TCT TCC CGA } \underline{\boldsymbol{A G A}} \\
\frac{\boldsymbol{C A} \boldsymbol{A} \text { CCA AAT CCT CTC }}{\text { TT } T \text { TCC CTA CAC TCA }} \\
\text { ACT GCC TGG TGA TAC } \\
\text { GAG GAT GGG CA }\end{array}$ & $\mathrm{N} / \mathrm{A}$ & 71 \\
\hline DNA 2 & DNA & $\begin{array}{l}\text { GGT GAT AAA ACG TGT } \\
\text { AGC AAG CTG TAA TCG } \\
\text { ACG GGA AGA GCA TGC } \\
\text { CCA TCC ACT ACT ATG } \\
\text { GCG }\end{array}$ & N/A & 63 \\
\hline DNA 3 & DNA & $\begin{array}{l}\text { AGG CAG TTG AGA CGA } \\
\text { ACA TTC CTA AGT CTG } \\
\text { AAA TTT ATC ACC CGC } \\
\text { CAT AGT AGA CGT ATC } \\
\text { ACC }\end{array}$ & N/A & 63 \\
\hline
\end{tabular}


TCG ATT ACA GCT TGC

DNA 4 DNA TAC ACG ATT CAG ACT

Type 1 -

Protector

DNA

AGG CAA GAA GTC ACT A 3' - TET

DNA

Type $2-$

Protector

DNA

AAA ACT AAC ATG AAA T 3' - TET

DNA

Type 3 -

Protector DNA

AAA AGA AGA AGT CAT C 3' - TET

DNA

Type 4-

Protector DNA

AAG AGA GGA TTT GGT T 3' - TET

DNA

Type 1 -

Capture DNA

DNA

AAC AAG GCA AGA AGT

CAC TAT CA

N/A

Type 2 -

Capture DNA

DNA

AGG CAA AAC TAA CAT

GAA ATG TT

N/A

Type 3 -

Capture

DNA

ACG TTA AAA GAA GAA

GTC ATC AT

N/A

Type 4-

Capture DNA DNA

GGA AAA GAG AGG ATT

TGG TTG TC

N/A 
Table S2. Sequences of the synthetic RNAs used in this study.

\begin{tabular}{|c|c|c|c|c|c|c|}
\hline Name & Source & Version & $\begin{array}{c}\text { Nucleic Acid } \\
\text { Type }\end{array}$ & Sequence & $\begin{array}{l}\text { Starting } \\
\text { Position }\end{array}$ & Bases \\
\hline $\begin{array}{l}\text { Type-1 } \\
\text { RNA }\end{array}$ & $\begin{array}{l}\text { Dengue } \\
\text { Virus } 1\end{array}$ & M87512.1 & RNA & $\begin{array}{c}\text { AAAUCAA } \\
\text { ACAAGGC } \\
\text { AAGAAGU } \\
\text { CAGGC }\end{array}$ & 10288 & 26 \\
\hline $\begin{array}{l}\text { Type-2 } \\
\text { RNA }\end{array}$ & $\begin{array}{l}\text { Dengue } \\
\text { Virus } 2\end{array}$ & M20558.1 & RNA & $\begin{array}{c}\text { GGUAGAA } \\
\text { GGCAAAA } \\
\text { CUAACAU } \\
\text { GAAAC }\end{array}$ & 10268 & 26 \\
\hline $\begin{array}{l}\text { Type-3 } \\
\text { RNA }\end{array}$ & $\begin{array}{l}\text { Dengue } \\
\text { Virus } 3\end{array}$ & M93130.1 & RNA & $\begin{array}{c}\text { CAAGGAC } \\
\text { GUUAAAA } \\
\text { GAAGAAG } \\
\text { UCAGG }\end{array}$ & 10351 & 26 \\
\hline $\begin{array}{l}\text { Type-4 } \\
\text { RNA }\end{array}$ & $\begin{array}{l}\text { Dengue } \\
\text { Virus } 4\end{array}$ & M14931.2 & RNA & $\begin{array}{c}\text { ACCUAGG } \\
\text { GAAAAGA } \\
\text { GAGGAUU } \\
\text { UGUGG }\end{array}$ & 10078 & 26 \\
\hline
\end{tabular}



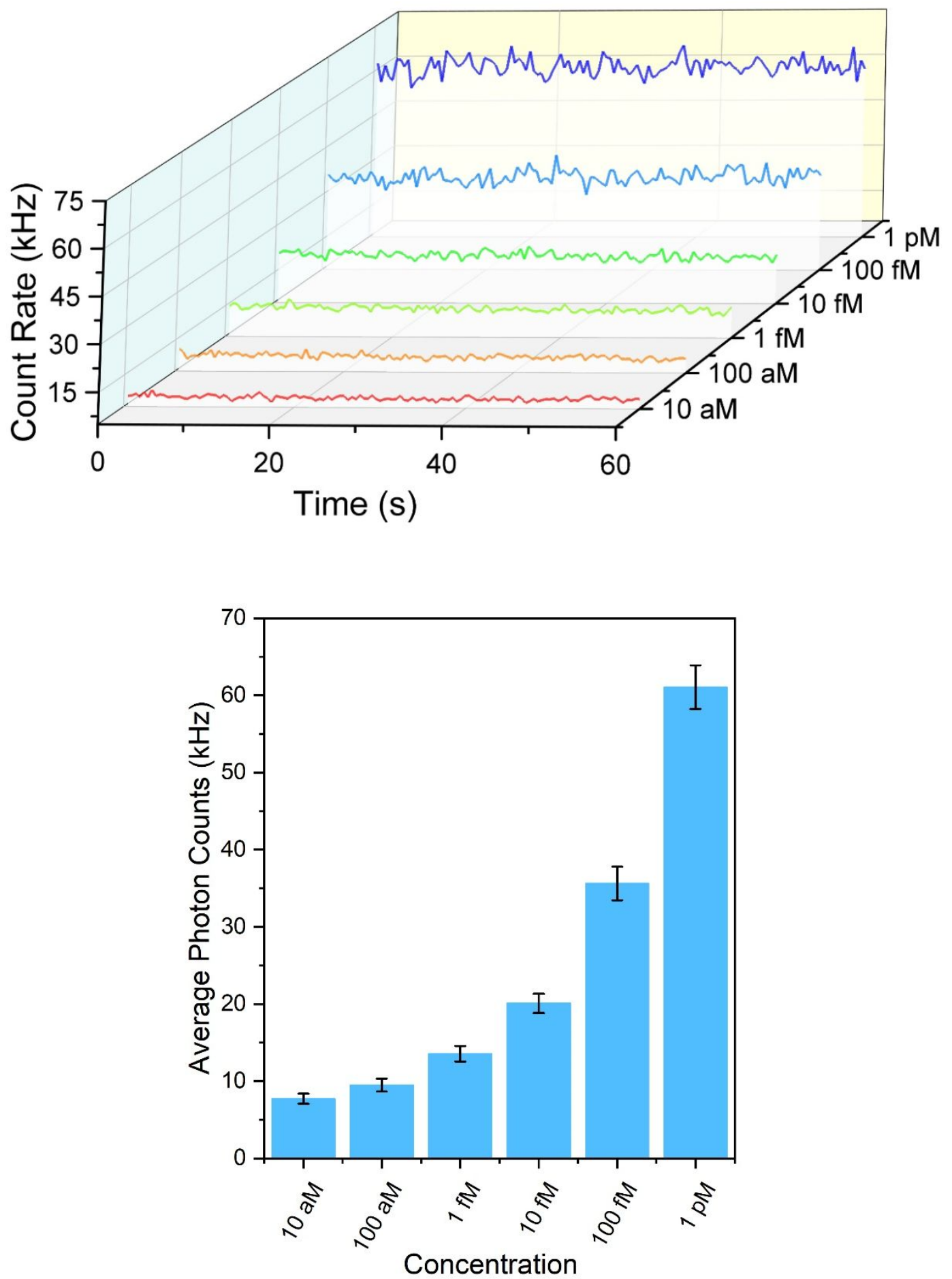

Figure S1. A) The photon count rate of the serotype 2 DNA tetrahedron in the presence of different concentrations of serotype 2 synthetic dengue viral RNA; B) The histogram of average photon counts of serotype 2 DNA tetrahedron in the presence of different concentration of serotype 2 synthetic dengue viral RNA after 60 seconds. 

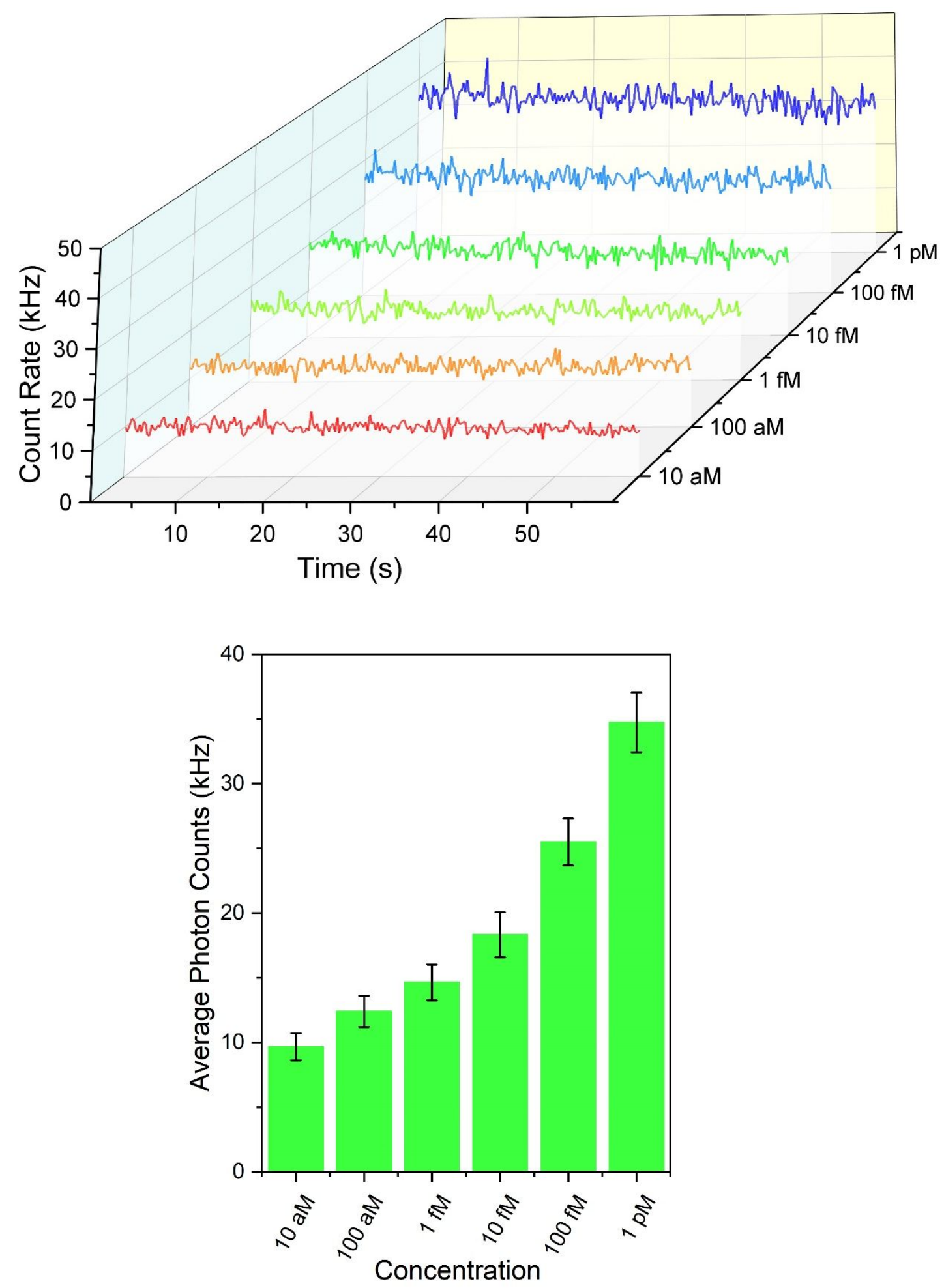

Figure S2. A) The photon count rate of the serotype 3 DNA tetrahedron in the presence of different concentrations of serotype 3 synthetic dengue viral RNA. B) The histogram of average photon counts of serotype 3 DNA tetrahedron in the presence of different concentration of serotype 3 synthetic dengue viral RNA after 60 seconds. 

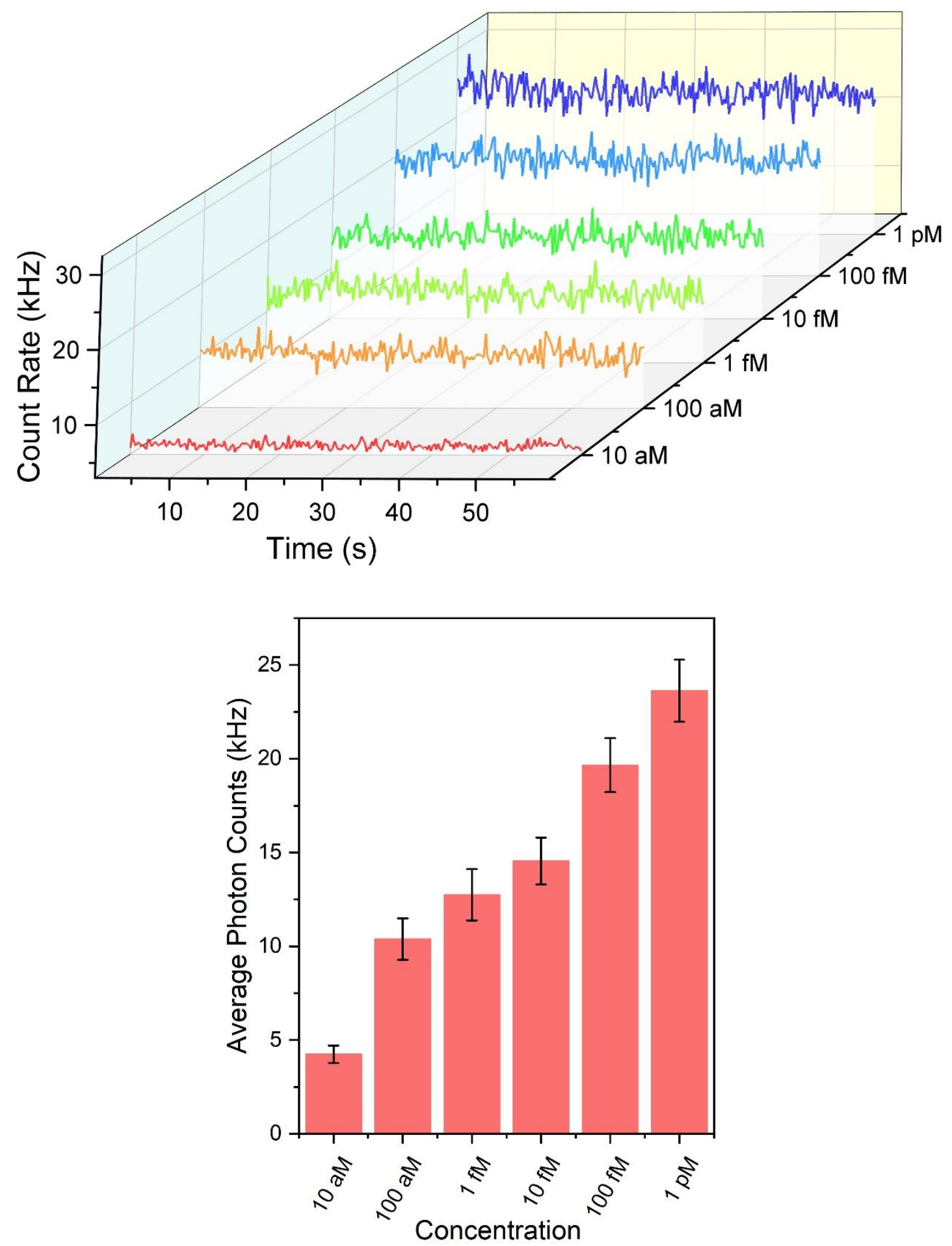

Figure S3. A) The photon count rate of the serotype 4 DNA tetrahedron in the presence of different concentrations of serotype 4 synthetic dengue viral RNA. B) The histogram of average photon counts of serotype 4 DNA tetrahedron in the presence of different concentration of serotype 4 synthetic dengue viral RNA after 60 seconds. 


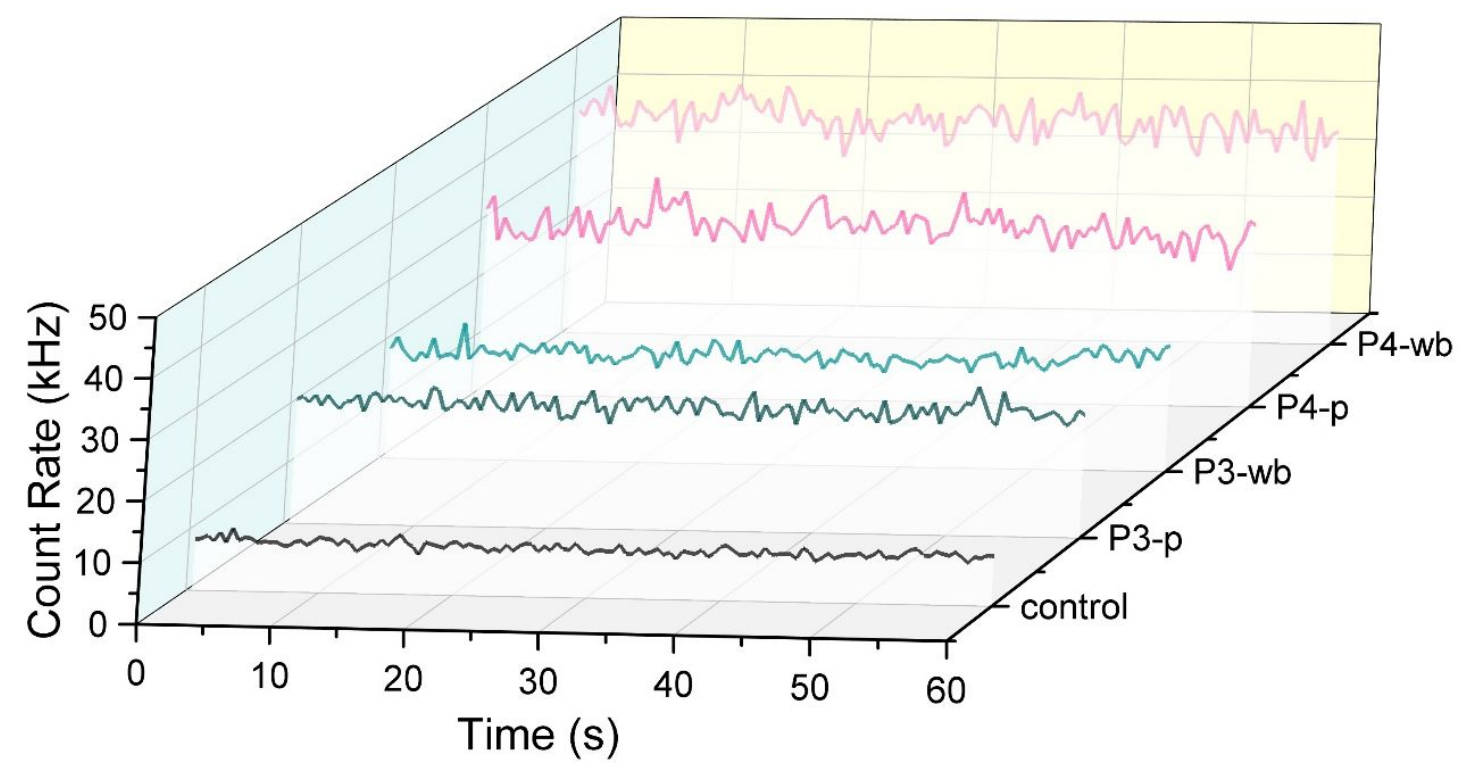

Figure S4. The photon count rates of serotype 2 DNA tetrahedron in the presence clinical dengue viral RNA samples. P3 and P4 indicate the third and the forth patients, $\mathrm{p}$ indicates the sample was extracted from plasma, wb indicates the sample was extracted from whole blood.

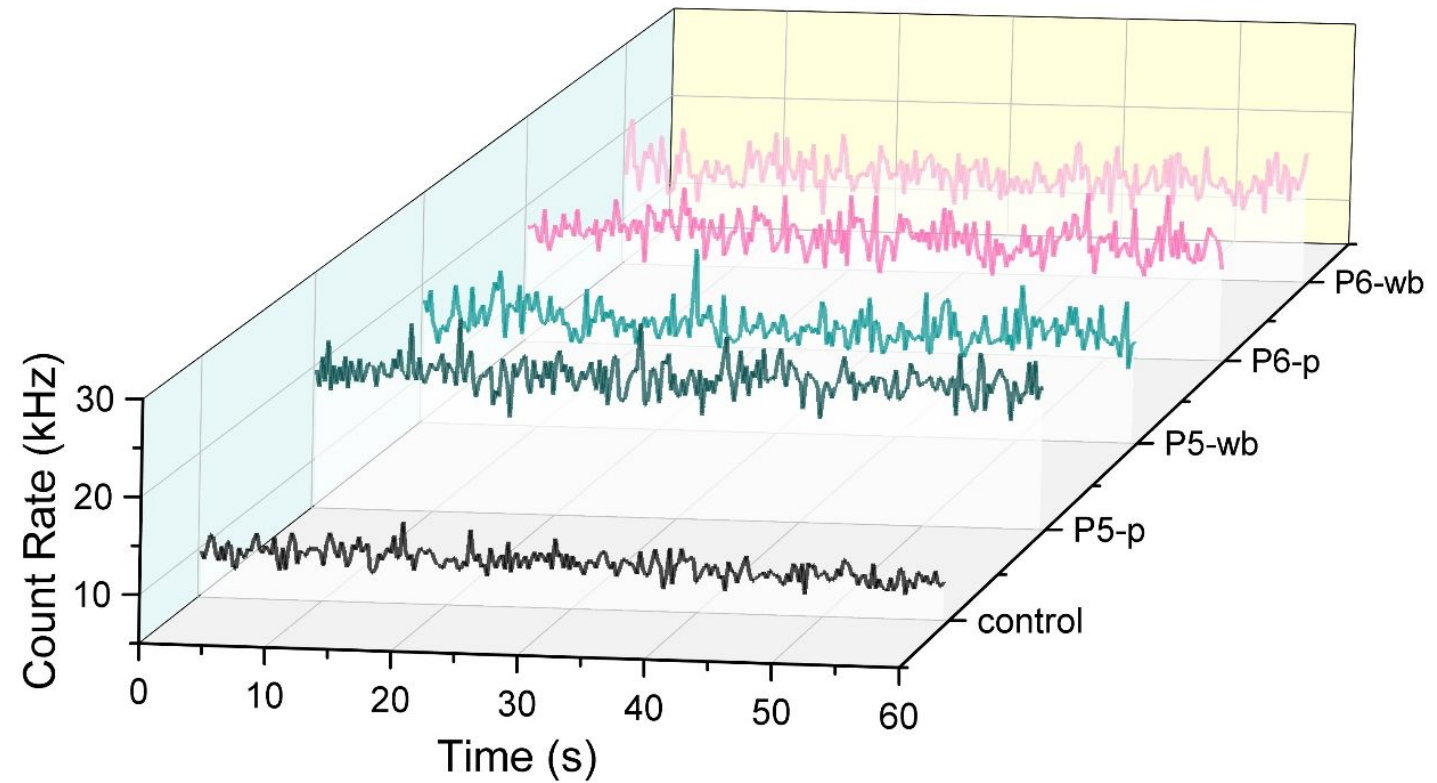

Figure S5. The photon count rates of serotype 3 DNA tetrahedron in the presence clinical dengue viral RNA samples. P5 and P6 indicate the fifth and the sixth patients, $\mathrm{p}$ indicates the sample was extracted from plasma, wb indicates the sample was extracted from whole blood. 




Figure S6. The photon count rates of serotype 4 DNA tetrahedron in the presence clinical dengue viral RNA samples. P7 and P8 indicate the seventh and the eighth patients, $p$ indicates the sample was extracted from plasma, wb indicates the sample was extracted from whole blood. 